\title{
Potential Use of Distinct Biomarkers (Trace Metals, Micronuclei and Nuclear Abnormalities) in a Heterogeneous Sample of Birds in Southern Brazil.
}

JOANA TOMAZELLI ( $\square$ joanatomazelli1@gmail.com )

FEEVALE University: Universidade FEEVALE https://orcid.org/0000-0001-6060-5579

Gabriela Zimmermann Prado Rodrigues

FEEVALE University: Universidade FEEVALE

Danielle Franco

Federal University of Rio Grande do Sul: Universidade Federal do Rio Grande do Sul

Mateus Santos de Souza

Federal University of Rio Grande do Sul: Universidade Federal do Rio Grande do Sul

Jorge Henrique Burghausen

FEEVALE University: Universidade FEEVALE

Jenifer Panizzon

FEEVALE University: Universidade FEEVALE

Juliana Machado Kayser

FEEVALE University: Universidade FEEVALE

Márcia Regina Loiko

FEEVALE University: Universidade FEEVALE

Anelise Schneider

FEEVALE University: Universidade FEEVALE

\section{Rafael Linden}

FEEVALE University: Universidade FEEVALE

Gunther Gehlen

FEEVALE University: Universidade FEEVALE

\section{Research Article}

Keywords: Bioindication, Body condition, Erythrocytes, Trace metals, Trophic Guilds, Wild birds.

Posted Date: March 22nd, 2021

DOI: https://doi.org/10.21203/rs.3.rs-306006/v1

License: (c) (i) This work is licensed under a Creative Commons Attribution 4.0 International License. Read Full License 
Version of Record: A version of this preprint was published at Environmental Science and Pollution Research on October 7th, 2021. See the published version at https://doi.org/10.1007/s11356-021-16657-6. 


\section{Abstract}

The analysis of metal concentrations in feathers and the micronuclei (MN) and other nuclear abnormalities (NA) test in birds are tools used for evaluating the impacts that anthropogenic actions have been causing to the environment and organisms. Here we used these biomarkers to investigate the response of birds to disturbances observed in three areas with different environmental characteristics (natural, agricultural and urban) in southern Brazil. We obtained a diverse sample (108 individuals from 25 species and 17 families) without significant differences in metal concentrations, frequency of $\mathrm{MN}$ and $\mathrm{AN}$ between sampling points. The concentrations of zinc $(\mathrm{Zn})$ and copper $(\mathrm{Cu})$ were significantly different between trophic guilds ( $\mathrm{Zn:} p=$ 0.0006, $\mathrm{Cu}: p=0.04$ ) and age classes ( $\mathrm{Zn}: p=0.01, \mathrm{Cu}: p=0.03$ ). Omnivore birds contributed to the increase in the number of $\mathrm{MN}(\triangle \mathrm{AlCc}: 0.00 ; w=0.40)$ and $\mathrm{NA}$, which was also influenced by age classes and body condition index $(\mathrm{BCl})(\Delta$ AICc: $0.00 ; w=0.34 ; \Delta$ AICc: $0.89 ; w=0.22 ; \Delta$ AlCc: $1.15 ; w=0.19 ; \Delta$ AlCc: $1.33 ; w=$ $0.18)$. We showed that in a diverse sample of birds, the variables analyzed affected each biomarker in distinct ways.

\section{Introduction}

Environmental discharges of many kinds of toxic compounds that result from anthropogenic activities such as pesticides, herbicides and industrial and vehicular atmospheric emissions, are associated with the degradation of natural habitats (Olayemi e Jagun 2014; Baesse et al. 2019). These compounds release metals into the environment and in high concentrations they can affect the health of various animal species, including birds (Pandiyan et al. 2020). The effects of metals on birds are related to growth, reproduction and, consequently, survival. Among the most important effects are decrease of testicular mass, spermatogenesis failure, decrease in egg production and egg mass, alterations in the eggshell, increase in embryo mortality and reduction of the incubation success (Burger e Gochfeld 1995). Besides that, these chemical compounds have mutagenic and carcinogenic potential, that can lead to genotoxicity, i.e., alterations in the levels of genetic compositions, increasing predisposition to chromosome-related disorders (Alimba and Bakare 2016; de Souza et al. 2017; Baesse et al. 2019).

In this context, quantification of metals and genotoxicity evaluation are frequently used tools of environmental monitoring in studies with birds. Birds are in a global level considered bioindicators of environmental quality (Solgi et al. 2020) because they quickly reflect environmental changes (Baesse et al. 2015), are easily found, live in many different habitats and occupy distinct trophic levels (Becker 2003; Abbasi et al. 2015a; Solgi et al. 2020). Moreover, the collection of biological samples, like feathers and blood, is considered a non-destructive procedure (Burger and Gochfeld 2000; Braga et al. 2010). Some authors have made efforts to evaluate the potential of birds as bioindicators by capturing a great number of species, but they rarely succeeded in identifying a good bioindicator species for genotoxic damage (Baesse et al. 2015) or in determining a species more sensitive to metal contamination (Abbasi et al. 2015a; Grúz et al. 2018). Other authors have restricted their attention to only one or a few species (Tsarpali et al. 2020; Mukhtar et al. 2020) and were able to achieve more robust conclusions, which is mainly attributed to known biological characteristics of the target species (Frixione and Rodríguez-Estrella 2020). 
Birds are exposed to contaminants through their interactions with the environment, by breathing, by food and water ingestion (Dauwe et al. 2000; Mukhtar et al. 2020) and by their contact with the ground (Leonzio et al. 2009; Souto et al. 2018). Feathers are widely used in environmental studies because of their capability of metal accumulation (Solgi et al. 2020) externally, via deposition and internally, through the bloodstream (Burger e Gochfeld 2000), reflecting the reflect long-term damage (Dauwe et al. 2000). Furthermore, the collection is considered a non-destructive technique (Burger and Gochfeld 1992).

The micronucleus (MN) test (Baesse et al. 2015) and the nuclear abnormalities (NA) test (Quero et al. 2016) are used for genotoxicity evaluation. MN and NA are formed when organisms are exposed to genotoxic agents (Angeletti e Carere, 2014). MN are small chromatin bodies outside the nucleus, generated by chromosomal break and spindle or centromere dysfunction during cell division (Bonisoli-Alquati 2014). NA are nuclear malformations attributable to errors during the development of erythrocytes (De Mas et al. 2015). These alterations represent impacts over DNA (Baesse et al. 2015) and are indicatives of recent exposure to contaminants (Santos et al. 2017).

Diet (Burger and Gochfeld 2000; De Mas et al. 2015; Abbasi et al. 2015a; Solgi et al. 2020), behavioral and feeding strategies (Costa et al., 2011; Tsarpali et al. 2020; Tasneem et al. 2020) and food resources availability (Fritsch et al. 2012; Quero et al. 2016) are some of the factors responsible for metal contamination and alterations of the numbers of MN and NA in birds. Birds in higher trophic levels present higher concentrations of metals (Zolfaghari et al. 2007; Lodenius and Solonen 2013; Abbasi et al. 2015) due to the biomagnification process (Burger and Gochfeld 1995; Tasneem et al. 2020). Food preferences might influence the levels of MN (Quirós et al. 2008) and the formation of NA (Quero et al. 2016). Quirós et al. (2008) found significant differences between heron nestlings species that feed in aquatic and terrestrial habitats, reporting higher levels of MN to terrestrial species, which usually feed on insects. However, there is limited information about the relation between $\mathrm{MN}$ and $\mathrm{NA}$ levels and diet in the literature.

Studies relating the presence of metals, MN, NA and the nutritional status of birds are scarce. High concentrations of metals were found in the liver and kidney of owls with low reserve of lipids (Esselink et al. 1995), however, in structures like feathers, this relation was investigated recently (Innangi et al. 2019) and more studies on the subject are needed. MN and NA were not correlated to the body condition (Tsarpali et al. 2020; Frixione and Rodríguez-Estrella 2020), but inferior health and/or nutritional status might increase the amount of damage to the cell nucleus (Santos et al. 2017).

Regarding wildlife exposure to chemical compounds, age is an important factor to be considered (Squadrone et al. 2016). Studies indicate that metal concentration in several tissues are frequently higher in adult birds (Burger and Gochfeld 1995; Leonzio et al. 2009; López-Perea et al. 2019; Innangi et al. 2019; Ackerman et al. 2019) because of long-term exposure to contaminated environments and consequent bioaccumulation (Grúz et al. 2018; Innangi et al. 2019). As the feathers of young individuals are recently formed and are less exposed to atmospheric conditions, they have smaller concentrations of metals (Dauwe et al. 2000). Age is also an important factor for MN an NA. Different generations might present different levels of these alterations (Santos et al. 2017; Tsarpali et al. 2020). MN and NA increased with the reduction of the age classes in aquatic birds (Santos et al. 2017), however, few studies tried to establish this relation. 
The Sinos River Hydrographic Basin (SRHB) had its vegetation cover altered by human activities initiated after the arrival of European immigrants and this process was intensified since 1940's (Franz et al. 2010). Deforestation to open areas for agriculture and cattle grazing is the main reason for the reduction of the vegetation cover in the basin to $10 \%$ of its original area. Besides that, these activities also contributed to the reduction of water quality (Figueiredo et al. 2010). In the metropolitan area, the high population and industrial density with its associated environmental problems (atmospheric emissions, industrial wastewater, lack of basic sanitation and intense vehicle traffic) contribute to the environmental degradation observed in this basin (Figueiredo et al. 2010). Previous studies with different bioindicators and biomarkers have shown an important environmental disturbance in the SRHB, caused by multiple factors. In fish, in addition to morphological alterations, high levels of metals have been reported (Dalzochio et al. 2018). In Tradescantia pallida var. purpurea, genotoxic damages influenced by low air quality were observed (Cassanego et al. 2015).

In this context, it is important to analyze the response of birds to the environmental impacts that occur in this region. The aim of this study was to evaluate the effect of anthropogenic disturbance in wild birds that inhabit areas with different environmental characteristics along the SRHB through the analysis of concentration of trace metals (chromium, manganese, zinc and copper) in feathers and the frequency of $\mathrm{MN}$ and NA in peripheral blood. Besides that, we evaluated whether there was variation of metals concentrations, $\mathrm{MN}$ and NA frequencies between sampling point, trophic guild, species, body condition index ( $\mathrm{BCl})$ and age classes. We hypothesized that birds inhabiting regions with less environmental impact would present lower concentrations of metals and lower frequencies of MN and NA in comparison to birds inhabiting more impacted regions. We also tested whether species respond in different ways to environmental disturbance, as well as whether adult birds and birds with more lipidic reserves would present higher metal concentration and whether young birds would present lower concentrations of metals and higher frequencies of MN and NA.

\section{Methodology \\ 2.1 Study area}

The study was conducted in two cities, Taquara and Novo Hamburgo, which are part of the Sinos River Hydrographic Basin. Three sampling sites were defined, each one located in a distinct environmental zone (natural, rural and urban zones) (Fig. 1). The climate, according to the Köppen classification, is Cfa, with no defined dry season and the average air temperature higher than $22^{\circ} \mathrm{C}$ in the hottest month (Peel et al., 2007). The areas are predominantly in the Semideciduous Seasonal Forest domain (Ibge 2012).

\subsubsection{Ilha River (Taquara city)}

The sampling site 1 (S1) is located near the source of the Ilha River (29³2'51.62"S 50³7'34.14"W) and its vegetation is typical of the highest altitude areas in the basin, i.e., it has a dense vegetation cover with the occurrence of exotic invader species, like the japanese raisin tree (Hovenia dulcis) (Fontanella et al., 2009). Some elements of Ombrophilous Forest are observed in this region, as it is in an ecotone between this plant formation and the Semideciduous Seasonal Forest (Comitesinos, 2016). This place is also characterized by 
surrounding areas with plantations of exotic species like Pinus sp. and Eucalyptus sp., There are also small farms and low population density.

The sampling site 2 (S2) is situated near the mouth of the llha River $\left(29^{\circ} 40^{\prime} 41.81^{\prime \prime} \mathrm{S} 50^{\circ} 44^{\prime} 25.30^{\prime \prime} \mathrm{W}\right)$. There are more houses and rural properties in this point than in $\mathrm{S} 1$, and activities like cattle raising are carried out in the region. The vegetation has been altered due to greater anthropogenic action (Fontanella et al. 2009). Native vegetation at this sampling site is restricted to riparian vegetation, which is surrounded by rice plantations.

\subsubsection{Parque Henrique Luís Roessler (Novo Hamburgo city)}

The sampling site 3 (S3) corresponds to the Parque Henrique Luís Roessler, a municipal conservation unit (Novo Hamburgo 2009), located in the urban area of the city of Novo Hamburgo (29 $40^{\prime} 53.67^{\prime \prime S} 51^{\circ}$ 6'33.38"W). The unit is surrounded by streets, houses and residential and commercial buildings. The native vegetation is characterized as early stage of succession. Some exotic species are present, as the Pinus elliotti (Cappelatti and Schmitt 2009). There are three springs within the unit, all of them contaminated by illegal discharge of domestic wastewater (Leuck, 2010).

\subsection{Capture of birds and data collection}

Bird were captured between November 2019 and May 2020, by mist-nets ( $9 \mathrm{~m}$ x 3 m, $15 \mathrm{~mm}$ mesh size). Each sampling site was sampled four times during this period, for approximately 5 hours in the morning. In order to avoid animal stress, the nets were checked every 15-30 minutes during the sampling period. Species identification followed Sigrist (2014). All individuals were marked with metallic rings supplied by CEMAVEICMBio and grouped by taxa according to the Brazilian Ornithological Records Committee (Comitê Brasileiro de Registros Ornitológicos) (de Piacentini et al. 2015).

Age classes determination of birds was based on information from feathers condition and other attributes from the plumage (molt and molt limits, shape of flight feathers, presence or absence of growing bars) (Ralph et al. 1996; Howell et al. 2003). Additional characteristics, like skull ossification, iris and bill color and commissure of the bill were observed (Ralph et al. 1996). In order to categorize the age of the birds, the system of classification based on the molting cycle - Wolfe-Ryder-Pyle (WRP) (Wolfe et al. 2010; Johnson et al. 2011; Johnson and Wolfe 2017) was used. Specimens were classified as juveniles when they were on, or presented signs of, the first cycle, i.e., they had juvenile plumage - acquired after leaving the nest - or formative plumage - acquired before reaching sexual maturity. Specimens that had finished the first cycle were classified as adults and a third category, undetermined age, was defined to include those animals that were not confidently classified as juveniles or adults.

Birds were grouped in four trophic guilds, following the classification proposed by Willman et al. (2014). This database defines trophic guilds based on the proportion of different food items consumed by each species. The guilds used in this study were: (1) insectivore, (2) herbivore/granivore and (3) omnivore.

Body condition can be estimated by dividing body mass by any linear measure of body size (Labocha and Hayes 2012). Therefore, the $\mathrm{BCl}$ (body condition index) was defined as the body mass divided by the tarsus length. Individuals with a high index value are heavier in relation to the skeleton size, and probably have 
better lipidic reserves (Gaiotti et al. 2020). The length of the tarsus (in $\mathrm{mm}$ ) was measured by a caliper rule and the mass was inferred with a digital weighing scale (precision of $0.1 \mathrm{~g}$ ).

A sample of blood was taken from the ulnar vein using a sterile needle $(0.45 \times 13 \mathrm{~mm}$ - subcutaneous standard). Blood smears (two for individuals) were immediately made on glass slides (Braga et al. 2010), which were dried at environmental temperature and fixed in methanol for 10 minutes.

For the analysis of metals, some contour feathers were taken from both sides of the chest of each bird, to reduce the possibility of harm (Burger and Gochfeld 2000). The feathers were placed in zipped plastic bags (Abbasi et al., 2015b), identified with a label containing the ring number of each bird and stored at room temperature.

\subsection{Washing, digestion and detection of metals in feathers}

In order to remove any contaminants deposited on its surface, the feathers were washed alternately with deionized water (1 minute) and PA acetone (1 minute) in decontaminated falcon tubes, which were shaken by hand (Veerle et al., 2004; Abdullah et al. 2015). This procedure was repeated three times. After washing, the feathers were dried at $80^{\circ} \mathrm{C}$ in a oven for 1 hour (Abbasi et al. 2015a).

The procedure for digestion of feathers followed adaptations of the methodology proposed by Reglero et al. (2008). The feathers (average of $0.03 \mathrm{~g}$ ) were initially immersed in a solution of $\mathrm{HNO}_{3}(65 \%)$. After that they were digested in a Microwave Accelerated Reaction System (MARS6 - CEM). Briefly, the feathers were calcined for 20 minutes until reaching the temperature of $180^{\circ} \mathrm{C}$, maintained at $180^{\circ} \mathrm{C}$ for more 15 minutes and then refrigerated for 15 minutes. Digested samples were diluted in a solution of $1520 \mu$ of $\mathrm{HNO}_{3}(65 \%)$ (Merck, Darmstadt, Germany) and $106 \mu$ l of Triton (Baker Analyzed $\circledast$ ) and had the volume adjusted to $100 \mathrm{ml}$ with Milli-Q $\mathrm{H}_{2} \mathrm{O}$.

A graphite furnace atomic absorption spectrometer (GFAAS - Perkin Elmer Analyst 600) was used for detection of metals. To provide quality control data, solutions used to dilute processed samples in each batch of analysis were taken as blank. The concentration of metals in blank solutions was always bellow detection limits. Detection limits for metals chromium (Cr), manganese, copper $(\mathrm{Cu})$ and zinc $(\mathrm{Zn})$ were $0.006,0.01$, 0.01 , and $0.3 \mu \mathrm{g} / \mathrm{g}$, respectively.

\subsection{Preparation and analysis of slides}

In laboratory, the slides were stained with Giemsa solution (5\%) for 10-15 minutes. After that, they were codified and analyzed by a single person (Alimba and Barake 2016) in an optical microscope with the highest magnification (1000x). For every bird, 3000 erythrocytes were analyzed (Hussain et al. 2012).

Criterions for identification of MN and NA were adapted from Quero et al. (2016). Thus, MN were identified as oval or circular structures with $1 / 3$ to $1 / 16$ of the nucleus size, with the same focal plane, color and texture as the nucleus, without bridges or chromatin overlaps (Tolbert et al. 1992) (Online Resource 1).

Among the NA, nuclear buds had the same morphology as the MN, but remained connected to the nucleus, without formation of chromatin bridges or a constriction at one extremity and had between $1 / 4$ and $1 / 3$ of the main nucleus size (Thomas et al. 2009). Binucleated cells presented two nuclei about the same size and 
color, with or without contact between them (Thomas et al. 2009; Jindal and Verma 2015). Nucleus that had a progressive narrowing and elongation at one extremity, were considered nuclear tails (Kursa and Bezrukov 2008). Nucleoplasmic bridges were considered as two nuclear structures of the same color, having equal or different sizes, connected by a chromatin bridge (Tolberd et al. 1992). A nucleus was considered notched when it had a well-defined notch that extended to a considerable depth and was limited by the nuclear envelope (Carrasco et al. 1990; Alimba and Bakare 2016) (Online Resource 1). Cases in which the morphology of the nucleus did not meet any of the preestablished criterions and/or raised doubts during the analysis were not included in the data.

\subsection{Data analysis}

In order to verify how much of the response variables (MN and NA) were explained by the predictor variables (sampling site, trophic guilds, species, BCl and age), we used Generalized Linear Models (GLM). The Poisson distribution was used in the MN models, while in the NA models the negative binomial distribution was used, to correct for data overdispersion. The link function used was the logarithm (link = log).

We built 27 candidate models for each response variable $(n=54)$, including null models (no effect). Model selection was performed according to the Akaike information criterion for small sample size (AICc) (Burnham and Anderson 2002), using the value of $\triangle \mathrm{AICC}<2$ (difference of AIC between given model and the best model) and the weight ( $w$ - weight of the evidence in favor of each model) for comparisons. The significance of each factor and the percentage of variation explained by the best models was calculated by applying the ANOVA test on the models residuals and subsequently applying the formula proposed by Ye et al. (2001), represented by the deviance of the variable divided by model residual deviance multiplied by 100 .

For the statistical analysis of the metals data, we tested normality using the Shapiro-Wilk test and applied the non-parametric Kruskal-Wallis test followed by the post-hoc Dunn's test for compare medians between points, species, trophic guilds and age classes. We used the Spearman correlation $(r)$ to verify the existence of correlation between metals and BCl. The analyses were performed using the packages "vegan", "AICcmodavg" and "MASS" in the software "R" (R Core Team 2020), with significance level of $a \leq 0,05$. The graphs were made in GraphPad Prism 8.0.1.

\section{Results}

Overall, 108 individuals (= 216 slides) from 25 species and 17 families were captured (Online Resource 2 ). Age classes and trophic guilds presented varied composition between sampling points (Online Resource 3 ). Adult Individuals were more frequently captured (57.4\%), followed by juveniles (35.8\%) and the undetermined age class (7.4\%). Insectivore (55.5\%) was the best represented trophic guild, followed by omnivore (40.7\%) and herbivore/granivore (3.8\%). The highest $\mathrm{BCI}$ was recorded in S3 (1.7), followed by P2 (1.56) and P1 (1.18).

\subsection{Detection of metals}

The concentrations of metals analyzed were not significantly different between sampling points (Online Resource 4). Significant differences were observed between some species, trophic guilds, age classes and 
$\mathrm{BCl}$. Concentrations of Zn were higher in Myiothlypis leucoblephara compared with Turdus albicollis ( $p=$ $0.01)$ and Turdus rufiventris $(p=0.02)$. Insectivores presented higher concentrations of $\operatorname{Zn}(p=0.02)$ and $\mathrm{Cu}$ $(p=0.03)$ than omnivores. The undetermined age class presented higher concentrations of $\mathrm{Zn}$ when compared with adult individuals $(p=0.001)$, and juveniles individuals presented higher concentrations of $\mathrm{Cu}$ than adults $(p=0.004)$ (Online Resource 5$)$. Only $\mathrm{Zn}$ and $\mathrm{Cu}$ were significantly correlated with the $\mathrm{BCl}$, both negative and weak correlations ( $\mathrm{Zn}: \mathrm{r}=-0.33, p=0.0008, \mathrm{Cr}: \mathrm{r}=-0.22, p=0.02)$.

\subsection{Micronuclei and nuclear abnormalities}

A total of $76 \mathrm{MN}$ and $3,267 \mathrm{NA}$ were recorded in $46.8 \%$ and $99 \%$ of the birds, respectively. Considering the number of captured individuals, the overall mean frequency of MN was $0.70 / 3,000$ (or $2.33 / 10,000$ ) and the overall mean frequency of NA was $5 / 3,000$ (or $16.68 / 10,000$ ). The most frequent NA were notched nuclei $(95,4 \%)$, binucleated cells $(82,4 \%)$, nuclear buds $(62,0 \%)$, nucleoplasmic bridges $(49,1 \%)$ and nuclear tails $(26,8 \%)$. While MN presented varied frequencies, NA presented similar number between sampling points (Online Resource 3).

\subsection{Generalized Linear Models (GLMs)}

Despite distinctive vegetation characteristics and anthropogenic pressure observed in the region of each sampling site, they did not influence the GLM (MN = $\Delta$ AICc: $5.53 ; w=0.03 ; \mathrm{NA}=\Delta$ AICc: $26.17 ; w=0.00)$.

The best supported GLM Poisson model showed that the omnivore guild contributed significantly and positively to data variation, being the factor responsible for the increase in the number of MN (Table 1). In all negative binomial GLM, the variable $\mathrm{BCl}$ significantly and positively influenced on the number of NA, showing that birds with better body condition have more NA. The presence of the herbivore/granivore guild decreased, while the omnivore guild increased the NA in some models. The adult and undetermined age classes reduced significantly the NA number in the second model, indicating that juveniles have more NA than other age classes (Table 1). 
Table 1

Results of the best GLM models selected for MN (Poisson) and NA (negative binomial) with parameters estimated under each model, standard error (SE), p value $(p)$, AlCc, $\Delta$ AlCc and the weight of the model $(w)$. The intercept values represent the insectivore guild and the juvenile age classes.

\begin{tabular}{|c|c|c|c|c|c|c|c|c|}
\hline Models & Variables & Estimates & SE & $\begin{array}{l}z- \\
\text { value }\end{array}$ & $p$ & AlCc & $\Delta \mathrm{AlCc}$ & $w$ \\
\hline \multirow{3}{*}{$\begin{array}{l}\text { MN } \\
\text { trophic } \\
\text { guild }\end{array}$} & Intercept & -0.6604 & 0.1796 & -3.677 & $<_{0.001}$ & 279.36 & 0.00 & 0.40 \\
\hline & Herbivore/granivore & -0.7259 & 1.0160 & -0.715 & 0.474 & & & \\
\hline & Omnivore & 0.6604 & 0.2345 & 2.816 & $\begin{array}{l}< \\
0.01\end{array}$ & & & \\
\hline \multirow{4}{*}{$\begin{array}{l}\text { NA } \\
\text { trophic } \\
\text { guild + } \\
\text { BCl }\end{array}$} & Intercept & 1.9945 & 0.2427 & 8.219 & $\dot{0}_{0.001}$ & 927.20 & 0.00 & 0.34 \\
\hline & Herbivore/granivore & -1.7553 & 0.6122 & -2.867 & $\begin{array}{l}<.01 \\
0.01\end{array}$ & & & \\
\hline & Omnivore & 0.6877 & 0.1997 & 3.444 & $\begin{array}{l}< \\
0.001\end{array}$ & & & \\
\hline & $\mathrm{BCl}$ & 0.6809 & 0.1662 & 4.097 & $<0.001$ & & & \\
\hline \multirow{8}{*}{$\begin{array}{l}\text { NA } \\
\text { age } \\
\text { classes } \\
+ \\
\text { trophic } \\
\text { guild * } \\
\text { BCl }\end{array}$} & Intercept & 2.2168 & 0.3725 & 5.951 & $<0.001$ & 928.09 & 0.89 & 0.22 \\
\hline & Adult & -0.3517 & 0.2078 & -1.693 & 0.09 & & & \\
\hline & Undetermined age & -0.7753 & 0.3887 & -1.995 & $\begin{array}{l}< \\
0.01\end{array}$ & & & \\
\hline & Herbivore/granivore & -0.9359 & 0.9711 & -0.964 & 0.33 & & & \\
\hline & Omnivore & -0.6173 & 0.8695 & -0.710 & 0.47 & & & \\
\hline & $\mathrm{BCl}$ & 0.6519 & 0.2673 & 2.439 & 0.01 & & & \\
\hline & Herbivore/granivore: $\mathrm{BCl}$ & -0.2619 & 0.3622 & -0.723 & 0.47 & & & \\
\hline & Omnivore:BCl & 0.8340 & 0.5222 & 1.597 & 0.11 & & & \\
\hline \multirow{5}{*}{$\begin{array}{l}\text { NA } \\
\text { trophic } \\
\text { guild * } \\
\text { BCl }\end{array}$} & Intercept & 1.7164 & 0.3210 & 5.347 & $<0.001$ & 928.35 & 1.15 & 0.19 \\
\hline & Herbivore/granivore & -0.6152 & 0.9678 & -0.636 & 0.52 & & & \\
\hline & Omnivore & -0.2575 & 0.8787 & -0.293 & 0.76 & & & \\
\hline & $\mathrm{BCl}$ & 0.8992 & 0.2350 & 3.827 & $\dot{0}_{0.001}$ & & & \\
\hline & Herbivore/granivore:BCl & -0.5466 & 0.3468 & -1.576 & 0.11 & & & \\
\hline
\end{tabular}

* significant $p$ value $(p \leq 0.05)$ 


\begin{tabular}{|c|c|c|c|c|c|c|c|c|}
\hline Models & Variables & Estimates & SE & $\begin{array}{l}z- \\
\text { value }\end{array}$ & $p$ & AlCc & $\Delta \mathrm{AlCc}$ & $w$ \\
\hline & Omnivore: $\mathrm{BCl}$ & 0.4922 & 0.5280 & 0.932 & 0.35 & & & \\
\hline \multirow{8}{*}{$\begin{array}{l}\mathrm{NA} \sim \\
\text { trophic } \\
\text { guild + } \\
\mathrm{BCl} \text { * } \\
\text { age } \\
\text { classes }\end{array}$} & Intercept & 1.4283 & 0.5516 & 2.589 & $\langle .001$ & 928.53 & 1.33 & 0.18 \\
\hline & Herbivore/granivore & -1.3864 & 0.6066 & -2.286 & $\begin{array}{l}< \\
0.05\end{array}$ & & & \\
\hline & Omnivore & 0.8309 & 0.2077 & 4.000 & $\begin{array}{l}< \\
0.001\end{array}$ & & & \\
\hline & $\mathrm{BCl}$ & 1.2284 & 0.4094 & 3.000 & $\hat{0}_{0.01}$ & & & \\
\hline & Adult & 0.7567 & 0.6847 & 1.105 & 0.26 & & & \\
\hline & Undetermined age & 1.130 & 1.4966 & 0.760 & 0.44 & & & \\
\hline & BCl:Adult & -0.7653 & 0.4584 & -1.670 & 0.09 & & & \\
\hline & BCl:Undetermined age & -2.3940 & 2.1153 & -1.132 & 0.25 & & & \\
\hline
\end{tabular}

The results of the ANOVA test of the MN model showed that the variable trophic guild was significant and explained $7.64 \%$ of the model (Table 2). In the NA GLM, the ANOVA test showed that the variables trophic guild and $\mathrm{BCl}$ were significant and explanatory in all models. The age classes also had significant contribution to the explanation of the second and fourth best models (Table 2). All models explained 119.03\% of data variation. 
Table 2

ANOVA results of the Generalized Linear Models for values of MN (Poisson) and NA (negative binomial), number of parameters (Df).

\begin{tabular}{|c|c|c|c|c|c|c|}
\hline Models & Df & Deviance & Residuals Df & Residual deviance & $p$ & $\%$ explained \\
\hline Null model & & & 107 & 126.91 & & \\
\hline \multicolumn{7}{|c|}{$\mathrm{MN} \sim$ trophic guild } \\
\hline Guild & 2 & 9.6977 & 105 & 117.22 & $<0.01$ & 7.64 \\
\hline Null model & & & 107 & 163.41 & & \\
\hline \multicolumn{7}{|c|}{$\mathrm{NA} \sim$ trophic guild $+\mathrm{BCl}$} \\
\hline Guild & 2 & 31.810 & 105 & 131.60 & $<0.001$ & 19.47 \\
\hline \multirow[t]{2}{*}{$\mathrm{BCl}$} & 1 & 11.998 & 104 & 119.61 & $<0.001$ & 7.34 \\
\hline & & & & & Total & 26.81 \\
\hline Null model & & & 107 & 173.85 & & \\
\hline \multicolumn{7}{|c|}{$\mathrm{NA} \sim$ age classes + trophic guild * $\mathrm{BCl}$} \\
\hline Age & 2 & 18.6850 & 105 & 155.17 & $<0.001$ & 10.75 \\
\hline Guild & 2 & 25.6706 & 103 & 129.50 & $<0.001$ & 14.76 \\
\hline $\mathrm{BCl}$ & 1 & 8.1230 & 102 & 121.37 & $<0.01$ & 4.67 \\
\hline \multirow[t]{2}{*}{ Guild:BCl } & 2 & 2.8403 & 100 & 118.53 & 0.24 & 1.63 \\
\hline & & & & & Total & 31.81 \\
\hline Null model & & & 107 & 167.28 & & \\
\hline \multicolumn{7}{|c|}{$\mathrm{NA} \sim$ trophic guild * $\mathrm{BCl}$} \\
\hline Guild & 2 & 32.594 & 105 & 134.69 & $<0.001$ & 19.48 \\
\hline $\mathrm{BCl}$ & 1 & 12.283 & 104 & 122.40 & $<0.001$ & 7.34 \\
\hline \multirow[t]{2}{*}{ Guild:BCl } & 2 & 3.415 & 102 & 118.99 & 0.28 & 2.04 \\
\hline & & & & & Total & 28.86 \\
\hline Null model & & & 107 & 173.06 & & \\
\hline \multicolumn{7}{|c|}{$\mathrm{NA} \sim$ trophic guild $+\mathrm{BCl} *$ age } \\
\hline Guild & 2 & 33.768 & 105 & 139.29 & $<0.001$ & 19.51 \\
\hline $\mathrm{BCl}$ & 1 & 12.710 & 104 & 126.58 & $<0.001$ & 7.34 \\
\hline Age & 2 & 5.755 & 102 & 120.83 & 0.05 & 3.32 \\
\hline
\end{tabular}

* significant $p$ value $(p \leq 0.05)$ 


\begin{tabular}{|lclllll|}
\hline Models & Df & Deviance & Residuals Df & Residual deviance & $\boldsymbol{p}$ & \% explained \\
\hline BCl:age & 2 & 2.391 & 100 & 118.44 & 0.30 & 1.38 \\
\hline & & & & Total & 31.55 \\
\hline & & & & & \\
\hline
\end{tabular}

\section{Discussion}

\subsection{Trace metals}

The overall mean concentration of $\mathrm{Zn}$ in feathers recorded in this study $(437.77 \pm 241.25 \mu \mathrm{g} / \mathrm{g})$ is similar to those recorded by Abdullah et al. (2015) in feathers of herons from polluted aquatic environments in Pakistan $(226$ to $529 \mu \mathrm{g} / \mathrm{g}$ ). However, the species M. leucoblephara presented mean concentration of $762,82 \pm 309,06$ $\mu \mathrm{g} / \mathrm{g}$, which is significantly higher when compared with T.rufiventris and T. albicollis (352.97 \pm 132.00 and $336.18 \pm 93.54 \mu \mathrm{g} / \mathrm{g}$, respectively). These values are higher than concentrations found in feathers of a passerine bird from a DDT contaminated area in Africa $(207.45$ a $291.51 \mu \mathrm{g} / \mathrm{g})$ (Baker et al. 2017). According to Tasneem et al. (2020), high concentrations of this metal in feathers might be related to deposition from exogenous sources, but Abdullah et al. (2015) argue that when there is a high concentration of $\mathrm{Zn}$ in the organism, it can be deposited in feathers, as a way of excretion.

The metal Mn presented an overall mean concentration of $29.63 \pm 16.74 \mu \mathrm{g} / \mathrm{g}$, which is comparable to the value found in a passerine species living in a gradient of industrial pollution (means from 17.4 to $43.8 \mu \mathrm{g} / \mathrm{g}$ ) (Janssens et al. 2001) and in an aquatic bird species (16 to $21.9 \mu \mathrm{g} / \mathrm{g}$ ) (Abdullah et al. 2015). In Passer domesticus, however, Baker et al. (2017) found concentrations ranging from 15.73 to $78.38 \mu \mathrm{g} / \mathrm{g}$.

Concentrations observed in the present study are high when compared with values reported in the literature but are not high enough to indicate manganese contamination. Manganese is an essential metal that participates in a series of biochemical reactions in the organisms (Abdullah et al. 2015), but exogenous contamination might occur through vehicular pollution, contaminated dust and food intake (Burger and Gochfeld; 1995; Abdullah et al. 2015).

The metal Cr presented an overall mean concentration of $2.41 \pm 1.84 \mu \mathrm{g} / \mathrm{g}$. This metal might have neurotoxic effects on birds (Burger and Gochfeld 2000) and these authors assert that concentrations higher than 2.80 $\mu \mathrm{g} / \mathrm{g}$ in feathers indicate contamination. The overall mean concentration of Cu found in the present study $(7.84 \pm 4.55 \mu \mathrm{g} / \mathrm{g}$ ) is low when compared to other studies in polluted areas (Manjula et al. 2015; Baker et al. 2017). According to Baker et al. (2017) exogenous contamination by this metal is related to anthropogenic sources, like emissions from fossil fuels and industrial activities. Our results, however, are similar to those recorded in passerine birds that inhabit an urban area in Pakistan ( $\mathrm{Cr}, 1.11 \pm 0.70$ to $1.95 \pm 0.16, \mathrm{Cu}, 2.19 \pm$ 0.81 to $4.14 \pm 0.20$ ) (Abbasi et al. 2015b).

\subsection{Micronuclei and nuclear abnormalities}

The overall mean frequency of MN found in the present study $(0.70 / 3,000$ or $2.33 / 10,000)$ is similar to the data in the literature. Baesse et al. (2019) found a mean of 1.04MN/10,000 and Baesse et al. (2015) reported 
a mean of $1.30 \mathrm{MN} / 5,000$ (ou $2.6 \mathrm{MN} / 10,000$ ) in different sized forest fragments close to urban areas. In coffee farms with different sizes and different productive capacities, the mean was 3 MN/10,000 (Souto et al. 2018), which is higher than the values reported in other studies, but the evaluated environments and the chosen species might have contributed to this value.

The NA most frequently found in this study (notched nucleus and binucleated cells) were also the most representative abnormalities in a community of birds from a desert environment (Quero et al. 2016) and in a falcon species from an island environment (Tsarpali et al. 2020). Notched nucleus was the second most frequent NA found in a falcon species in an agricultural area (Frixione and Rodríguez-Estrella 2020), but the causes and the mechanism behind the formation of this abnormality are unknown (Quero et al. 2016). The presence of a great number of binucleated cells in birds have been related to exposure to particular contaminants, like in Japanese quails (Coturnix japonica) exposed to landfill leachate (Alimba and Bakare 2016) and atrazine (Hussain et al. 2012) and in Australian parakeets (Melopsittacus undulates) exposed to tannery effluents (de Souza et al. 2017). These chemical substances might inhibit the cytokinesis during cell division (Alimba and Bakare 2016), affecting its final stages (de Faria et al. 2018).

\subsection{Influence of the sampling points}

Although our sampling points are located in regions with different environmental characteristics, which are apparently impacted by different levels of anthropogenic pressure, our results did not indicate different levels of contamination between these regions. None of the evaluated metals or the frequency of MN and NA presented significant differences between sampling points. Moreover, all metals presented the highest concentrations on S1, and this sampling point had the second highest frequency of MN, followed by S2. Thus, this sampling point, located in a region that apparently has a lower degree of impacts, might be being contaminated by a wide range of pollutants that could enter even preserved areas by the movement of atmospheric air (Abbasi et al. 2015), as already reported by Alves et al. (2018) in the SRBH.

Even though we did not find any significant relation, the impact on birds that inhabit urban areas was evidenced by a higher frequency of MN in S3. Stocker (2019) reports higher levels of MN in birds that live near the airport area in Porto Alegre, Brazil, when compared with captive animals. Baesse et al. (2019) found a higher number of $\mathrm{MN}$ in forest fragments close to urbanization, suggesting that the greater the vehicles traffic near the fragment, the greater the number of MN in birds. Sasamori et al. (2012) assessing the genotoxic potential of the air using Tradescantia Pallida as a bioindicator in S3, found a higher frequency of $\mathrm{MN}$ in plants in this place when compared with a control group, suggesting that pollution from motor vehicles might be the source of the genotoxic agent in this region. However, based on our results, there is no clear distinction between potential genotoxicity and metal contamination between sampling points.

\subsection{Influence of trophic guilds}

In this study, trophic guilds had a relevant contribution to the results, but were related in different ways to the concentrations of metals and genotoxicity. Insectivores presented concentrations of $\mathrm{Zn}$ and $\mathrm{Cu}$ significantly higher than omnivores. GLM results indicated that a generalist diet (omnivore) is related to the increase in the number of $\mathrm{MN}$ and $\mathrm{NA}$. 
Our results are in agreement with studies that found higher levels of metals in insectivore birds in comparison to omnivore birds (Leonzio et al. 2009; Gong et al. 2012; Abbasi et al. 2015b; Ackerman et al. 2019). Besides that, we observed that a particular insectivore species presented concentration of Zn significantly higher than omnivores birds. However, food intake is not the primary source of Zn contamination in birds (Philpot et al. 2019), because the transference of this metal through the food chain is modified by homeostatic mechanisms to maintain adequate physiological levels (Gong et al. 2012). The concentration of $\mathrm{Zn}$ found in this guild $(465.61 \pm 221.38 \mu \mathrm{g} / \mathrm{g})$ is higher than in insectivore passerines in Pakistan $(41.58 \mathrm{to} 51.04 \mu \mathrm{g} / \mathrm{g})$ (Abbasi et al. 2015b) and in other insectivore birds from the same country (75.25 $\mu \mathrm{g} / \mathrm{g})$ (Abbasi et al. 2015a).

The concentration of $\mathrm{Cu}$ in the insectivore guild was not high $(9.20 \pm 5.99 \mu \mathrm{g} / \mathrm{g})$, but it was higher than values reported in insectivore passerines $(1.04$ to $1.58 \mu \mathrm{g} / \mathrm{g})$ and in other insectivore birds from Pakistan $(2.88 \mu \mathrm{g} / \mathrm{g})$ (Abbasi et al. 2015a; b). The detection of high concentrations of $\mathrm{Cu}$ is related to exogenous contamination (Leonzio et al. 2009). A recent study with samples from the food chain and levels of metals in feathers, muscle and blood, indicates that there is no trophic transference of Cu between terrestrial species of birds (Tasneem et al. 2020).

Due to the nature of the metals analyzed, it is not possible to affirm that the significance of the results is related to contamination through the diet. Environment characteristics (Fritsch et al. 2012) and the interaction of birds with it might influence the food items that will be consumed and consequently influence the availability of metals (Abbasi et al. 2015a; Berglund 2018), because species have distinct foraging characteristics and behavior, and can explore different areas when searching for food (Fritsch et al. 2012; Berglund 2018).

Omnivore birds are able to change their diet when exposed to adverse environmental conditions (Willis 1979). In forests, omnivores can forage near its edges, being favored by plant heterogeneity found in these areas (Bispo e Scherer-Neto 2010). Besides that, due to feeding plasticity, omnivore populations tend to stabilize or to grow in fragmented environments (Anjos et al. 2004). Therefore, animals belonging to this guild are more able to adapt to different environments and explore a wide range of food resources in different strata, what exposes them to many contaminants.

In this regard, studies relating the presence of MN and/or NA with the diet of birds are scarce. Souto et al. (2018) tested the hypothesis that insectivore birds would present more MN in coffee farms, because there is a great number of insects in these places. However, the omnivore guild presented the highest MN frequency, in opposition to their hypothesis and corroborating our results. Similarly, Oliveira (2020) observed that in two different environment (conserved and agricultural) omnivore species presented the highest frequencies of $\mathrm{MN}$, and no significant NA differences were found.

The herbivore/granivore guild did not show significant influence on the MN number, but when associated with the $\mathrm{BCl}$ this guild contributed negatively to the increase in NA in some GLM. Plants have lower concentrations of metals when compared with insects (Gong et al. 2012), therefore herbivores/granivores might be less susceptible to contamination through the food chain. The sample size of this guild, however, was not representative in this study.

\subsection{Influence of body condition}


Our results reveled a negative association between $\mathrm{Zn}$ and $\mathrm{Cu}$ with the increase of the $\mathrm{BCl}$, even though it had a small relevance. The negative association of metals like selenium (Se) (López-Perea et al. 2019) and mercury ( $\mathrm{Hg}$ ) (Ackerman et al. 2019) in blood, and cadmium (Ca) and barium (Ba) in feathers (Innangi et al. 2019) with the body condition was also reported in the literature.

Ackerman et al. (2019) suggest two hypotheses to explain these observations. The first one considers that concentrations of metals might be reduced because they are diluted as the body mass increases. The second one considers the opposite relationship, observing that the highest concentrations of metals are found in birds with lower body condition. The last hypothesis corroborates the affirmation of Lodenius and Solonen (2013), that malnutrition might be responsible for physiological stress and worse body condition, increasing the concentration of metals at the expense of body condition. These discussions support our results, as we observed insectivore birds (with the lowest $\mathrm{BCl}$ ) presenting the highest $\mathrm{Zn}$ and $\mathrm{Cu}$ concentrations.

Regarding genotoxicity, $\mathrm{BCl}$ and trophic guilds contributed to the increase in the number of NA, according to the GLM and the ANOVA test on models' residuals. Our results indicate that omnivore birds (with higher $\mathrm{BCl}$ ) have more NA. Frixione and Rodríguez-Estrella (2020), studying a falcon species in an area of agricultural production, did not find significant relationship between $\mathrm{MN}$ and $\mathrm{NA}$ frequencies with the body condition index, but smaller birds presented higher frequencies of NA (Frixione and Rodríguez-Estrella 2020). Souto et al. (2018) showed that the size of a bird influenced the number of MN, explaining $95 \%$ of $M N$ frequency.

The variation of body condition might be related to the reproductive period, in which birds expend more energy (Kitaysky et al. 1999), but it is directly related to the diet (Brown and Sherry 2006). Birds with specialized feeding habits (insectivores) might be affected by fluctuations in resource availability, so that the generalist diet is favored, because it has greater flexibility (Teles et al. 2017).

\subsection{Age classes influence}

The undetermined age class presented higher concentration of $\mathrm{Zn}$ than the adults, however, a few individuals were present in this age class. In this study, concentrations of $\mathrm{Cu}$ were higher in juveniles when compared with adults $(9.18 \pm 4.26$ and $6.31 \pm 3.13 \mu \mathrm{g} / \mathrm{g}$ respectively), in opposition to information available in the literature.

Copper (Cu) is an essential metal, which is required in low concentrations in birds (Grúz et al. 2018). Besides that, it has affinity with keratin, a protein involved in feathers development and growing (Baker et al. 2017). The accumulation of metals in feathers of juvenile birds might occur during growth, when the nestling receives food from its parents, which might be different from the adult diet (Fritsch et al. 2012; Grúz et al. 2018). Berglund et al. (2011) report that nestlings of a passerine species presented higher levels of essential elements (cadmium, nickel and zinc) in their liver when compared to adult females, in a polluted environment. Fritsch et al. (2012) found higher concentrations of metals in juveniles than in adults of a passerine species in a gradient of polluted areas. Among the explanations, the authors highlight the hypothesis of the forage behavior, in which younger and less experienced individuals would not consume the same food items consumed by the adults (Fritsch et al. 2012). 
The age classes influenced the number of NA in the second best GLM and the significance of the ANOVA test based on model's residuals. Birds in the undetermined age class and adult birds presented lower numbers of NA when compared to juveniles. Santos et al. (2017) reported that juveniles of white stork (Ciconia ciconia) in the process of rehabilitation presented higher frequencies of NA and MN than adults. In a falcon species the MN frequency in juveniles was higher than in adults (Tsarpali et al. 2020). Zúñiga-González et al. (2000) comment that this result is might be attributable to the reticuloendothelial system (involved with the removal of old erythrocytes from the blood), which only matures in older birds, so juveniles would not be able to eliminate damaged and old erythrocytes so efficiently as the adults.

\section{Conclusion}

We defined the field sampling based on previous studies in which many species of birds were captured and during the analysis of biomarkers, some of them revealed potential to be used as bioindicators of environmental quality (Abbasi et al. 2015a; Baesse et al. 2015; Baesse et al. 2019; Quero et al. 2016; Souto et al. 2018). However, we observed that in our study area, this kind of "random" capture was not effective.

This is partially due to the fact that only a few species had similar sampling sizes in all sampling sites, what restricted comparisons between individuals of the same species from different sites, making it difficult to evaluate their bioindicator potential. Our samples were predominantly composed of a few individuals from many different species with different interspecific biological and ecological characteristics (behavior, diet, availability of food resources, preferences for distinct foraging areas) and also potential physiological differences (absorption, retention and excretion of contaminants) (Burger and Gochfeld 2000; Costa et al., 2011; Quero et al. 2016). Therefore, they might respond in varied ways to exposure to contaminants (Eens et al. 1999; Manjula et al. 2015).

The mainly results in our study were mainly related to the diet. Therefore, in studies using birds as bioindicators, we recommend that researchers focus on one or a few species which have well-known specific characteristics, like the forage area and feeding preferences (Tsarpali et al. 2020; Frixione e RodríguezEstrella, 2020).

This study was a pioneer in using wild birds in the SRHB region and, despite the limitations described, we concluded that trophic guilds, age classes and $\mathrm{BCl}$ significantly influenced the accumulation of trace metals and the frequency of MN and NA. It was not possible, however, to determine the exact interaction between the biomarkers used to understand the response of the birds to the environmental pollution in the study area.

\section{Declarations}

\section{Ethical approval}

All procedures performed in this study were approved by the Ethics Committee on the Use of Animals of the Feevale University (Comitê de Ética no Uso de Animais, CEUA-FEEVALE), project 02.19.075, and by Brazilian environmental agencies (SISBIO authorization 70856-1 and CEMAVE autorization 159/2019).

Consent to participate "Not applicable" 
Consent for publication "Not applicable"

Availability of data and materials "Not applicable"

\section{Competing interests}

The authors declare that they have no conflict of interest

\section{Funding}

This work was funded by the Coordenação de Aperfeiçoamento de Pessoal de Nível Superior - Brasil (CAPES).

\section{Author's contributions}

JT was responsible for conceptualizing the project, data analysis, acquisition of financial support, methodology (capture of birds, data and biological samples collection, slide analysis and processing of feathers) and for writing the manuscript. GZPR helped with the methodology (MN and NA analysis, and feather processing), data analysis and manuscript writing. DF helped with the methodology (capture of birds), data analysis and manuscript writing. MSdeS helped with the methodology (capture of birds and collection of biological samples) and revised the language and grammar of the manuscript. JP helped with the methodology (capture of birds and collection of biological samples). JHB did part of data analysis and helped with the methodology (capture of birds and collection of biological samples). JMK helped with the methodology (processing of feathers). MRL helped with the methodology (collection of biological samples). AS helped with the methodology (analysis and detection of metals in the samples). RL helped with the methodology (analysis and detection of metals in the samples). GG helped with the conceptualization of the project, was responsible for the supervision and validation of the project, acquisition of financial support and helped with manuscript writing.

\section{Acknowledgements}

We thank the Prefeitura Municipal de Novo Hamburgo, through the Diretoria de Proteção Ambiental for granting research authorization at the Parque Henrique Luís Roessler.

\section{References}

1. Abbasi NA, Jaspers V LB, Chaudhry M J I, Ali S, Malik RN (2015a) Influence of taxa, trophic level, and location on bioaccumulation of toxic metals in bird's feathers: A preliminary biomonitoring study using multiple bird species from Pakistan. Chemosphere 120: 527-537. https://doi.org/10.1016/j.chemosphere.2014.08.054

2. Abbasi NA, Khan MU, Jaspers V LB, Chaudhry M J., Malik RN (2015b) Spatial and interspecific variation of accumulated trace metals between remote and urbane dwelling birds of Pakistan. Ecotoxicol Environ Saf 113: 279-286. https://doi.org/10.1016/j.ecoenv.2014.11.034 
3. Abdullah M, Fasola M, Muhammad A, Malik SA, Bostan N, Bokhari H, Kamran MA, Shafqat, MN, Alamdar A, Khan M, Ali N, Eqani SAMAS (2015) Avian feathers as a non-destructive bio-monitoring tool of trace metals signatures: A case study from severely contaminated areas. Chemosphere 119: 553-561. https://doi.org/10.1016/j.chemosphere.2014.06.068

4. Ackerman JT, Hartman CA, Herzog MP (2019) Mercury contamination in resident and migrant songbirds and potential effects on body condition. Environ Pollut 246: 797-810. https://doi.org/10.1016/j.envpol.2018.11.060

5. Alimba CG, Bakare AA (2016) In vivo micronucleus test in the assessment of cytogenotoxicity of landfill leachates in three animal models from various ecological habitats. Ecotoxicology 25(2): 310-319. https://doi.org/10.1007/s10646-015-1589-3

6. Alves DD, Backes E, Rocha-Uriartt L, Riegel RP, de Quevedo DM, Schmitt JL, da Costa GM, Osório D MM (2018) Chemical composition of rainwater in the Sinos River Basin, Southern Brazil: a source apportionment study. Environ Sci Pollut Res 25(24): 24150-24161. https://doi.org/10.1007/s11356-0182505-1

7. Angeletti D, Carere C (2014) Comparative ecogenotoxicology: Monitoring the DNA of wildlife. Cur Zool., 60(2): 252-254. https://doi.org/10.1093/czoolo/60.2.252

8. Anjos L, Zanette L, Lopes EV (2004). Effects of Fragmentation on the Bird Guilds of the Atlantic Forest in North Paraná, Southern Brazil. Ornitol Neotrop 15: 137-144

9. Baesse CQ, Tolentino VCde M, Morelli S, Melo C (2019) Effect of urbanization on the micronucleus frequency in birds from forest fragments. Ecotoxicol Environ Saf 171: 631-637. https://doi.org/10.1016/j.ecoenv.2019.01.026

10. Baesse CQ, Tolentino VCde M, Silva AM da, Silva AdeA, Ferreira, GÂ, Paniago LPM, Nepomuceno JC, Melo Cde (2015) Micronucleus as biomaker of genotoxicity in birds from Brazilian Cerrado. Ecotoxicol Environ Saf 115: 223-228. https://doi.org/10.1016/j.ecoenv.2015.02.024

11. Baker NJ, Dahms S, Gerber R, Maina J, Greenfield R (2017) Metal Accumulation in House Sparrow (Passer domesticus) from Thohoyandou, Limpopo Province, South Africa. Afr Zool 52(1): 43-53. https://doi.org/10.1080/15627020.2017.1293491

12. Becker PH (2003) Biomonitoring with birds. In: Markert BA, Breure AM, Zechmeister HG (eds) Bioindicators and biomonitors. Elsevier science. Elsevier, Amsterdam, pp 677-736

13. Berglund ÅMM, Koivula MJ, Eeva T (2011) Species- and age-related variation in metal exposure and accumulation of two passerine bird species. Environ Pollut 159(10): 2368-2374. https://doi.org/10.1016/j.envpol.2011.07.001

14. Berglund ÅMM (2018) Evaluating blood and excrement as bioindicators for metal accumulation in birds. Environ Pollut 233:1198-1206. https://doi.org/10.1016/j.envpol.2017.10.031

15. Bispo AA, Scherer-Neto $P$ (2010) Avian assemblage in a remnant of the Araucaria Forest in the Southeast Parana, Brazil. Biota Neotrop 10 (1): 121-130.

16. Bonisoli-Alquati, A. (2014). Avian genetic ecotoxicology: DNA of the canary in a coalmine. Curr Zool, 60(2), 285-298. https://doi.org/10.1093/czoolo/60.2.285 
17. Braga, E. M., Belo, N. de O., \& Pinheiro, R. T. (2010). Técnicas para estudo de hemoparasitos em aves. In Ornitologia e Conservação: Ciência Aplicada, Técnicas de Pesquisa e Levantamento, Rio de Janeiro: Technical books Editora, pp. 397-411. (in Portuguese)

18. Brown DR, Sherry TW (2006) Food supply controls the body condition of a migrant bird wintering in the tropics. Oecologia 149(1): 22-32. https://doi.org/10.1007/s00442-006-0418-z

19. Burger J, Gochfeld M (1992) Trace element distribution in growing feathers: Additional excretion in feather sheaths. Archives Environ Contam Toxicol 23(1): 105-108. https://doi.org/10.1007/BF00226002

20. Burger, J., \& Gochfeld, M. (1995). Biomonitoring of heavy metals in the pacific basin using avian feathers. Environ Toxicol Chem, 14(7), 1233-1239. https://doi.org/10.1002/etc.5620140716

21. Burger J, Gochfeld, M (2000) Metal levels in feathers of 12 species of seabirds from Midway Atoll in the northern Pacific Ocean. Sci Total Environ 257(1): 37-52. https://doi.org/10.1016/S0048-9697(00)004964

22. Burnham KP, Anderson, DR (2002) Model selection and multi-model inference: a practical informationtheoretic approach. 2nd ed.

23. Cappelatti L, Schmitt, JL (2009) Caracterização da flora arbórea de um fragmento urbano de Floresta estacional semidecidual no Rio Grande Do Sul, Brasil. Pesquisas Botânica 60: 341-354. (in Portuguese)

24. Carrasco KR, Tilbury KL, Myers MS (1990) Assessment of the Piscine Micronucleus Test as an in situ Biological indicator of Chemical Contaminant Effects. Can J Fish Aquat Sci 47(11): 2123-2136. https://doi.org/10.1139/f90-237

25. Cassanego MBB, Sasamori MH, Petry CT,Droste A (2015) Biomonitoramento do potencial genotóxico do ar em Tradescantia pallida var. purpurea sob condições climáticas na bacia do Rio dos Sinos, Rio Grande do Sul, Brasil. Brazilian J Biol 75(4): S79-S87. https://doi.org/10.1590/1519-6984.05514. (in Portuguese)

26. COMITESINOS (2016) Comitê de Gerenciamento da Bacia Hidrográfica do Rio dos Sinos. Atlas do Projeto Verde Sinos: um recorte ambiental da bacia hidrográfica do rio dos Sinos (p. 116). http://www.comitesinos.com.br/arquivos/projeto-verdesinos--atlas-do-projeto-verdesinos--um-recorteambiental-da-bacia-hidrografica-do-rio-dos-sinos--produzido-sob-coordenacao-do-comitesinos-2016-0202-1506984016.pdf. Acessed 28 january 2021

27. Dalzochio T, Rodrigues GZP, Simões LA., de Souza MS, Petry, IE, Andriguetti NB, Silva GJH, da Silva LB, Gehlen G (2018) In situ monitoring of the Sinos River, southern Brazil: water quality parameters, biomarkers, and metal bioaccumulation in fish. Environ Sci Pollut Res 25(10): 9485-9500. https://doi.org/10.1007/s11356-018-1244-7

28. Dauwe T, Bervoets L, Blust R, Pinxten R, Eens M (2000) Can excrement and feathers of nestling songbirds be used as biomonitors for heavy metal pollution? Archives Environ Contam Toxicol 39(4): 541-546. https://doi.org/10.1007/s002440010138

29. de Faria DBG, Montalvão MF, de Souza JM, Mendes BdeO, Malafaia G, Rodrigues ASdeL (2018) Analysis of various effects of abamectin on erythrocyte morphology in Japanese quails (Coturnix japonica). Environ Sci Pollut Res 25(3): 2450-2456. https://doi.org/10.1007/s11356-017-0677-8 
30. De Mas E, Benzal J, Merino S, Valera F, Palacios MJ, Cuervo JJ, Barbosa A (2015) Erythrocytic abnormalities in three Antarctic penguin species along the Antarctic Peninsula: biomonitoring of genomic damage. Polar Biol 38(7): 1067-1074. https://doi.org/10.1007/s00300-015-1667-2

31. de Piacentini VQ et al (2015) Annotated checklist of the birds of Brazil by the Brazilian Ornithological Records Committee. Brazilian J of Ornitol 23(2): 91-298. https://doi.org/10.1007/bf03544294

32. de Souza JM, Montalvão MF, da Silva AR, Rodrigues, ASdeL, Malafaia G (2017) A pioneering study on cytotoxicity in Australian parakeets (Melopsittacus undulates) exposed to tannery effluent. Chemosphere 175: 521-533. https://doi.org/10.1016/j.chemosphere.2017.02.087

33. Eens M, Pinxten R, Verheyen RF, Blust R, Bervoets L (1999) Great and blue tits as indicators of heavy metal contamination in terrestrial ecosystems. Ecotoxicol Environ Saf 44(1): 81-85. https://doi.org/10.1006/eesa.1999.1828

34. Esselink H, Geld FMVD, Jager LP, Posthuma-Trumpie GA, Zoun PEF, Baars AJ (1995) Biomonitoring heavy metals using the barn owl (Tyto alba guttata): Sources of variation especially relating to body condition. Archives Environ Contam Toxicol 28(4): 471-486. https://doi.org/10.1007/BF00211630

35. Figueiredo JAS, Drumm E, Rodrigues MAS, Spilki FR (2010) The Rio dos Sinos watershed: An economic and social space and its interface with environmental status. Brazilian J Biol 70: 1131-1136. https://doi.org/10.1590/s1519-69842010000600001

36. Fontanella A et al (2009) Diagnóstico ambiental da bacia hidrográfica do Rio da llha, Taquara, Rio Grande do Sul, Brasil. Revista Brasileira de Biociências 7(1): 23-41. (in Portuguese)

37. Franz I, Cappelatti L, Barros MP (2010) Bird community in a forest patch isolated by the urban matrix at the Sinos River basin, Rio Grande do Sul State, Brazil, with comments on the possible local defaunation. Brazilian J Biol 70:1137-1148. https://doi.org/10.1590/s1519-69842010000600002

38. Fritsch C, Coeurdassier M, Faivre B, Baurand PE, Giraudoux P, Brink, NWVD, Scheifler R (2012) Influence of landscape composition and diversity on contaminant flux in terrestrial food webs: A case study of trace metal transfer to European blackbirds Turdus merula. Sci Total Environ 432: 275-287. https://doi.org/10.1016/j.scitotenv.2012.06.004

39. Frixione MG, Rodríguez-Estrella R (2020) Genotoxicity in American kestrels in an agricultural landscape in the Baja California peninsula, Mexico. Environ Sci Pollut Res 27(36): 45755-45766. https://doi.org/10.1007/s11356-020-10392-0

40. Gaiotti MG, Webster MS, Macedo RH (2020) An atypical mating system in a neotropical manakin. Royal Soc Open Sci 7(1). https://doi.org/10.1098/rsos.191548

41. Gong Q, Jin ZM, Zou HF (2012) Concentrations of copper, zinc and manganese in Tree Sparrow (Passer montanus) at Jixi, Heilongjiang Province, China. J Forestry Res 23(2): 319-322. https://doi.org/10.1007/s11676-012-0259-z

42. Grúz A, Déri J, Szemerédy G, Szabó K, Kormos É, Bartha A, Lehel J, Budai P (2018) Monitoring of heavy metal burden in wild birds at eastern/north-eastern part of Hungary. Environ Sci Pollut Res 25(7): 63786386. https://doi.org/10.1007/s11356-017-1004-0

43. Howell SNG, Corben C, Pyle P, Rogers DI (2003) The first basic problem: A review of molt and plumage homologies. Condor 105(4): 635-653. https://doi.org/10.1650/7225 
44. Hussain R, Mahmood F, Khan A, Javed MT, Rehan S, Mehdi T (2012) Cellular and biochemical effects induced by atrazine on blood of male Japanese quail (Coturnix japonica). Pestic Biochem Physiol 103(1): 38-42. https://doi.org/10.1016/j.pestbp.2012.03.001

45. Ibge (Instituto Brasileiro de Geografia e Estatística) (2012) Manual técnico da vegetação brasileira: Sistema fitogeográfico inventário das formações florestais e campestres técnicas e manejo de coleções botânicas procedimentos para mapeamentos (p. 275). (in Portuguese)

46. Innangi M, De Rosa D, Danise T, Fozzi I, Giannotti M, Izzo M, Trifuoggi M, Fioretto A (2019) Analysis of 11 trace elements in flight feathers of Italian Sparrows in southern Italy: A study of bioaccumulation through age classes, variability in three years of sampling, and relations with body condition. Sci Total Environ 651: 2003-2012. https://doi.org/10.1016/j.scitotenv.2018.10.105

47. Janssens E, Dauwe T, Bervoets L, Eens M (2001) Heavy metals and selenium in feathers of great tits (Parus major) along a pollution gradient. Environ Toxicol Chem 20(12): 2815-2820. https://doi.org/10.1002/etc.5620201221

48. Jindal R, Verma S (2015) In vivo genotoxicity and cytotoxicity assessment of cadmium chloride in peripheral erythrocytes of Labeo rohita (Hamilton). Ecotoxicol Environ Saf 118: 1-10. https://doi.org/10.1016/j.ecoenv.2015.04.005

49. Johnson El, Wolfe JD (2017) Molt in Neotropical Birds: life, story and age criteria. Boca Raton, Florida.

50. Johnson El, Wolfe JD, Ryder, TB, Pyle, P (2011) Modifications to a molt-based ageing system proposed by Wolfe et al. (2010). J field Ornithol 82(4): 422-424. https://doi.org/10.1111/j.15579263.2011.00345.x

51. Kitaysky AS, Wingfield JC, Piatt JF (1999) Dynamics of food availability, body condition and physiological stress response in breeding Black-legged Kittiwakes. Functional Ecol 13(5): 577-584. https://doi.org/10.1046/j.1365-2435.1999.00352.x

52. Kursa M, Bezrukov V (2008) Health status in an antarctic top predator: micronuclei frequency and white Blood cell differentials in the south polar skua (Catharacta maccormicki). Polarforschung,77(1): 1-5. https://doi.org/10.2312/polarforschung.77.1.1

53. Labocha MK, Hayes JP (2012) Morphometric indices of body condition in birds: A review. J field Ornithol 153(1): 1-22. https://doi.org/10.1007/s10336-011-0706-1

54. Leonzio C, Bianchi N, Gustin M, Sorace A, Ancora S (2009) Mercury, lead and copper in feathers and excreta of small passerine species in relation to foraging guilds and age of feathers. Bull Environ Contam Toxicol 83(5): 693-697. https://doi.org/10.1007/s00128-009-9789-2

55. Leuck S (2010) Monitoramento e classificação das águas do Parque Municipal Henrique Luis Roessler de Novo Hamburgo. Trabalho de Conclusão de Curso de Graduação. Universidade Feevale, Novo Hamburgo,Brasil. (in Portuguese)

56. Lodenius M, Solonen T (2013) The use of feathers of birds of prey as indicators of metal pollution. Ecotoxicology 22(9): 1319-1334. https://doi.org/10.1007/s10646-013-1128-z

57. López-Perea JJ, Laguna C, Jiménez-Moreno M, Martín-Doimeadios RCR, Feliu J, Mateo R.(2019) Metals and metalloids in blood and feathers of common moorhens (Gallinula chloropus) from wetlands that 
receive treated wastewater. Sci Total Environ 646: 84-92.

https://doi.org/10.1016/j.scitotenv.2018.07.265

58. Manjula M, Mohanraj R, Devi MP (2015) Biomonitoring of heavy metals in feathers of eleven common bird species in urban and rural environments of Tiruchirappalli, India. Environ Monit Assess 187(5): 110. https://doi.org/10.1007/s10661-015-4502-x

59. Mukhtar H, Chan CY, Lin YP, Lin, CM (2020) Assessing the association and predictability of heavy metals in avian organs, feathers, and bones using crowdsourced samples. Chemosphere 252.

https://doi.org/10.1016/j.chemosphere.2020.126583

60. Muñoz AP, Kéry M, Martins PV, Ferraz G (2018) Age effects on survival of Amazon forest birds and the latitudinal gradient in bird survival. Auk 135(2): 299-313. https://doi.org/10.1642/AUK-17-91.1

61. Novo Hamburgo (2009) Decreto $n^{\circ} 4129 / 2009$, de 21 de dezembro de 2009. Declara o Parque Municipal Henrique Luís Roessler Unidade de Conservação Municipal, e dá outras providências. (in Portuguese)

62. Olayemi O, Jagun A (2014) Micronucleus as a Biomarker of Genotoxicity in Village Weaver Bird (Ploceus cucullatus). World’s Vet J 6(1): 48-53. https://doi.org/10.5455/wvj.20141045

63. Oliveira EDRS (2020) Avaliação genotóxica em aves silvestres do Cerrado. Dissertação de Mestrado Instituto Federal de Educação, Ciência e Tecnologia Goiano, Rio Verde, Goiás, Brasil. (in Portuguese)

64. Pandiyan J, Mahboob S, Jagadheesan R, Elumalai K, Krishnappa K, Al-Misned F, Ali Kaimkhani Z, Govindarajan M (2020) A novel approach to assess the heavy metal content in the feathers of shorebirds: A perspective of environmental research. J King Saud Univ - Sci 32(7): 3065-3071. https://doi.org/10.1016/j.jksus.2020.08.014

65. Peel MC, Finlayson BL, McMahon TA (2007) Updated world map of the Köppen-Geiger climate classification. Hydrol Earth Syst Sci 11(5): 1633-1644. https://doi.org/10.5194/hess-11-1633-2007

66. Philpot SM, Lavers JL, Nugegoda D, Gilmour ME, Hutton I, Bond AL (2019) Trace element concentrations in feathers of seven petrels (Pterodroma spp.). Environ Sci Pollut Res 26(10): 9640-9648. https://doi.org/10.1007/s11356-019-04406-9

67. Quero AA M, Ferré DM, Zarco A, Cuervo PF, Gorla NBM (2016) Erythrocyte micronucleus cytome assay of 17 wild bird species from the central Monte desert, Argentina. Environ Sci Pollut Res 23(24): 2522425231. https://doi.org/10.1007/s11356-016-7638-5

68. Quirós L, Ruiz X, Sanpera C, Jover L, Piña B (2008) Analysis of micronucleated erythrocytes in heron nestlings from reference and impacted sites in the Ebro basin (N.E. Spain). Environ Pollut 155(1): 81-87. https://doi.org/10.1016/j.envpol.2007.10.030

69. R Core Team (2020) A language and environment for statistical computing. http://www.r-project.org/

70. Ralph CJ, Geupel GR, Pyle P, Martin TE, Desante DF, Milá B, John C, Geoffrey R, Thomas E, David F (1996) Manual de métodos de campo para el monitoreo de aves terrestres. Pacific Southwest Research Station, Albany

71. Reglero MM, Monsalve-González L, Taggart MA, Mateo R (2008) Transfer of metals to plants and red deer in an old lead mining area in Spain. Sci Total Environ 406(1-2): 287-297.

https://doi.org/10.1016/j.scitotenv.2008.06.001

Page 23/26 
72. Santos CSA, Brandão R, Monteiro MS, Bastos AC, Soares AMVM, Loureiro S (2017) Assessment of DNA damage in Ardea cinerea and Ciconia ciconia: A 5-year study in Portuguese birds retrieved for rehabilitation. Ecotoxicol Environ Saf 136: 104-110. https://doi.org/10.1016/j.ecoenv.2016.10.039

73. Sasamori MR, Endres Júnior D, Barbosa, MD, Schmitt JL, Droste, A. Active monitoring of urban air with a simple short-term Tradescantia pallida var. purpurea bioassay under different temperature conditions. Brazilian J of Biosci 10:1679-2343.

74. Sigrist, T. (2014). Avifauna brasileira, 1st ed. Avis Brasilis, São Paulo. (in Portuguese)

75. Solgi E, Mirzaei-Rajeouni E, Zamani A (2020) Feathers of Three Waterfowl Bird Species from Northern Iran for Heavy Metals Biomonitoring. Bull Environ Contam Toxicol 104(6): 727-732. https://doi.org/10.1007/s00128-020-02852-7

76. Souto HN, Júnior, EOdeC, Campos CF, Rodrigues TS, Pereira BB, Morelli S (2018) Biomonitoring birds: the use of a micronuclei test as a tool to assess environmental pollutants on coffee farms in southeast Brazil. Environ Sci Pollut Res 25(24): 24084-24092. https://doi.org/10.1007/s11356-018-2466-4

77. Squadrone S, Abete MC, Brizio P, Monaco G, Colussi S, Biolatti C, Modesto P, Acutis PL, Pessani D, Favaro $L$ (2016) Sex- and age-related variation in metal content of penguin feathers. Ecotoxicology 25(2): 431438. https://doi.org/10.1007/s10646-015-1593-7

78. Stocker J (2019) O impacto da contaminação aeroportuária em aves de rapina. Dissertação de Mestrado Universidade La Salle. Canoas, Rio Grande do Sul, Brasil. (in Portuguese)

79. Tasneem F, Abbasi NA, Iqbal Chaudhry MJ, Mashiatullah A, Ahmad SR, Qadir A, Malik RN (2020) Dietary proxies $(\delta 15 \mathrm{~N}, \delta 13 \mathrm{C})$ as signature of metals and arsenic exposure in birds from aquatic and terrestrial food chains. Environ Research, 183. https://doi.org/10.1016/j.envres.2020.109191

80. Teles DRF, Dantas T, De Melo, C (2017) Body condition of five passerines in a forest fragment and associated factors. Brazilian J of Ornitol 25(2): 102-109. https://doi.org/10.1007/bf03544385

81. Thomas P, Holland N, Bolognesi C, Kirsch-Volders M, Bonassi S, Zeiger E, Knasmueller S, Fenech M (2009) Buccal micronucleus cytome assay. Nature Protocols 4(6): 825-837. https://doi.org/10.1038/nprot.2009.53

82. Tolbert PE, Shy CM, Allen JW (1992) Micronuclei and other nuclear anomalies in buccal smears: methods development. Mutat Res 271(1): 69-77. https://doi.org/10.1016/0165-1161(92)90033-I

83. Tsarpali V, Kassara C, Barboutis C, Papadimitraki M, Kloukinioti M, Giokas S, Dailianis S (2020) Assessing the seasonal and intrinsic variability of neurotoxic and cyto-genotoxic biomarkers in blood of free-living Eleonoras' falcons. Sci Total Environ 711. https://doi.org/10.1016/j.scitotenv.2019.135101

84. Veerle J, Tom D, Rianne P, Lieven B, Ronny B, Marcel E (2004) Erratum: The importance of exogenous contamination on heavy metal levels in bird feathers. A field experiment with free-living great tits, Parus major. J Environ Monit 6(7): 356-360. DOI: 10.1039/b314919f.

85. Willis E (1979) The composition of avian communities in remanescent woodlots in southern Brazil. Papéis Avulsos de Zoologia. São Paulo 33(1): 1-25

86. Wilman H. Belmaker J. Simpson J. de la Rosa C, Rivadeneira MM, Jetz W (2014) EltonTraits 1.0: Specieslevel foraging attributes of the world's birds and mammals. Ecology 95(7): 2027-2027. https://doi.org/10.1890/13-1917.1 
87. Wolfe JD, Ryder TB, Pyle P (2010) Using molt cycles to categorize the age of tropical birds: An integrative new system. J field Ornithol 81(2): 186-194. https://doi.org/10.1111/j.1557-9263.2010.00276.x

88. Ye, Y, Al-Husaini M, Al-Baz A (2001) Use of generalized linear models to analyze catch rates having zero values: The Kuwait driftnet fishery. Fisheries Res 53(2): 151-168. https://doi.org/10.1016/S01657836(00)00287-3

89. Zolfaghari G, Esmaili-Sari A, Ghasempouri SM, Kiabi BH (2007) Examination of mercury concentration in the feathers of 18 species of birds in southwest Iran. Environ Res 104(2): 258-265. https://doi.org/10.1016/j.envres.2006.12.002

90. Zúñiga-González G, Torres-Bugarín O, Luna-Aguirre J, González-Rodríguez A, Zamora-Perez A, GómezMeda BC, Ventura-Aguilar AJ, Ramos-lbarra ML, Ramos-Mora A, Ortíz GG, Gallegos-Arreola MP (2000) Spontaneous micronuclei in peripheral blood erythrocytes from 54 animal species (mammals, reptiles and birds): Part two. Mutat Res - Genetic Toxicology and Environmental Mutagenesis 467(1): 99-103. https://doi.org/10.1016/S1383-5718(00)00021-8

\section{Figures}

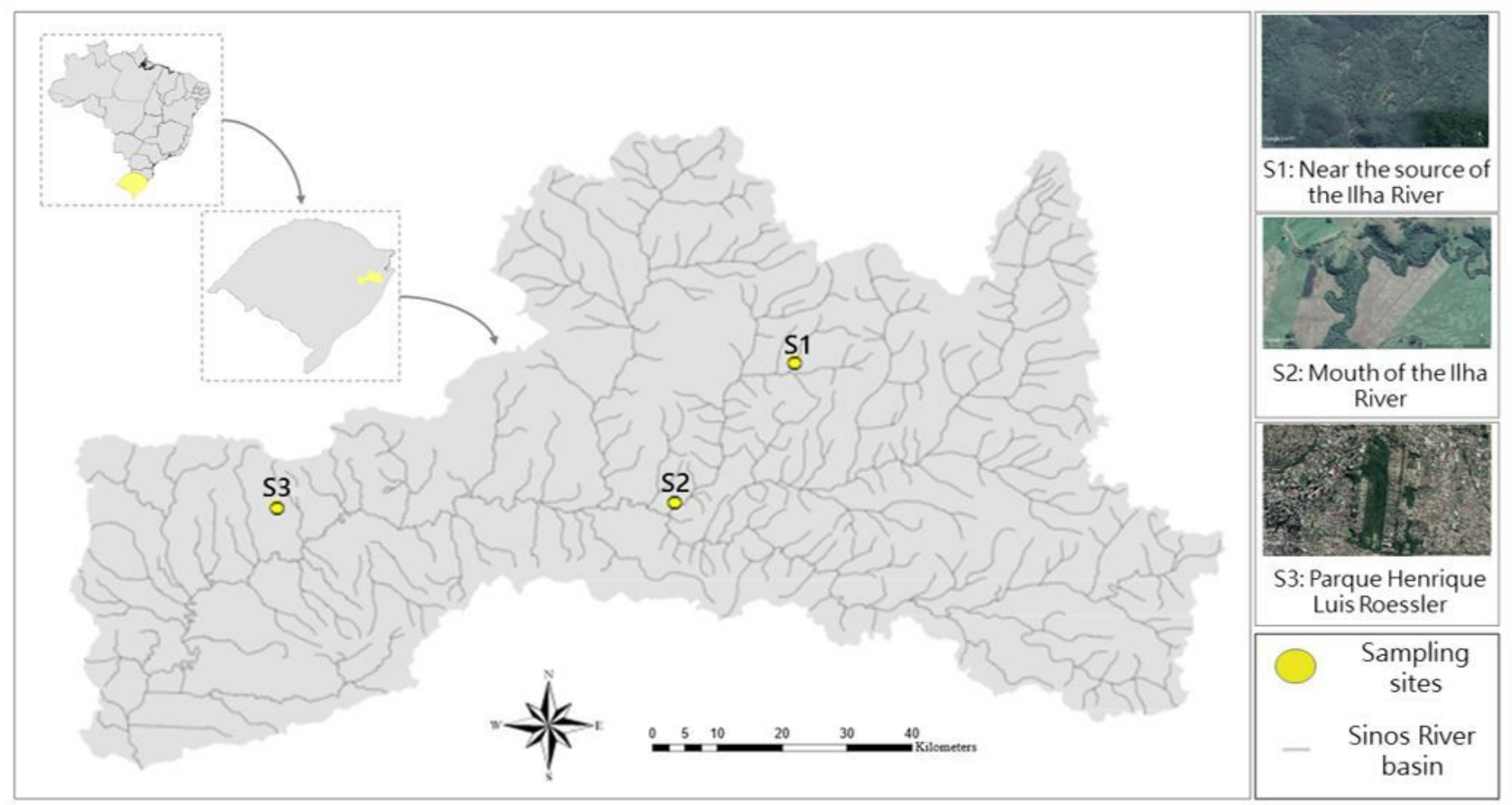

\section{Figure 1}

Map with the location of the sampling points in the SRHB, Rio Grande do Sul State, Brazil. Sampling sites 1 (S1 - natural zone) and 2 (S2 - rural zone) are located in Taquara city, while sampling site 3 (S3 - urban zone) is located in Novo Hamburgo city. Note: The designations employed and the presentation of the material on this map do not imply the expression of any opinion whatsoever on the part of Research Square concerning 
the legal status of any country, territory, city or area or of its authorities, or concerning the delimitation of its frontiers or boundaries. This map has been provided by the authors.

\section{Supplementary Files}

This is a list of supplementary files associated with this preprint. Click to download.

- RESOURCESONLINE.docx 